\title{
An efficient method for the production of transgenic plants of peanut (Arachis hypogaea L.) through Agrobacterium tumefaciens-mediated genetic transformation
}

\author{
Kiran K. Sharma *, Vanamala Anjaiah \\ Genetic Resources and Enhancement Program, Genetic Transformation Laboratory, \\ International Crops Research Institute for the Semi-Arid Tropics (ICRISAT), Patancheru, Andhra Pradesh 502 324, India
}

Received 20 March 2000; received in revised form 20 May 2000; accepted 22 May 2000

\begin{abstract}
Cotyledon explants from mature peanut seeds (Arachis hypogaea L.) were optimized to obtain adventitious shoot buds with high frequencies ( $>90 \%$ ). Efficient transformation of these cotyledons by using Agrobacterium tumefaciens strain C58 carrying neomycin phosphotransferase II (nptII) and B-glucuronidase (GUS; uid A), or coat protein gene of the Indian peanut clump virus (IPCV cp) and $n p t I I$ on binary vectors (pBI121; pROKII:IPCVcp) led to the production of a large percentage (55\%) of transgenic plants. Transformed individuals were obtained through selection on medium containing $125 \mathrm{mg}^{-1}$ kanamycin. A large number of independently transformed plants (over 75) were successfully transplanted to the glasshouse. Integration of the transgenes and stable genetic transformants in the progeny were assessed by PCR amplification of 700-bp fragment of nptII and 585-bp of IPCVcp genes, and Southern blot hybridizations in the T1 generation of transgenic plants. Analysis of 35 transgenic plants of T1 generation from the progeny of a single transformation event suggested the segregation of a single copy insert in a 3:1 Mendelian ratio. On an average, 120-150 days were required between the initiation of explant transformation and transfer of rooted plants to the greenhouse. The cotyledon regeneration system proved to be an excellent vehicle for the production of a large number of independently transformed peanut plants. Shoot formation was rapid and prolific, and a large proportion of these shoots developed into fertile plants. The method reported here provides new opportunities for the crop improvement of peanut via genetic transformation. (C) 2000 Elsevier Science Ireland Ltd. All rights reserved.
\end{abstract}

Keywords: Agrobacterium tumefaciens; Arachis hypogaea; Groundnut; Indian peanut clump virus; Shoot regeneration; Transgenic plants

\section{Introduction}

Peanut or groundnut (Arachis hypogaea L.) is an economically important oil and protein rich crop, whose seeds contain about $43 \%$ oil and $25 \%$ protein that has a significant impact in tropical and sub-tropical regions of Asia, Africa, and North and South America. There are several constraints to the productivity of the peanut crop that result in great economic losses annually [1]. Although some of the wild relatives of A. hypogaea have been identified as resistance source to several

\footnotetext{
* Corresponding author. Tel.: + 91-403296161; fax: +91-403241239.

E-mail address: k.sharma@cgiar.org (K.K. Sharma).
}

diseases and pests [2], the success in transferring the desirable traits to cultivated varieties has been limited due to reproductive barriers, and frequent failures in the interspecific crosses. The application of biotechnological methods for the improvement of important crop plants of the semi-arid tropics have been shown to hold great potential [1]. Genetic transformation approach allows for introducing novel genes that are not accessible normally by conventional cross-breeding, i.e. limited by sexual incompatibility. Although several reports on efficient regeneration from diverse explants of peanut have been published [3-6], not much success with genetic transformation of Arachis species has been achieved. This is due to 
the lack of efficient protocols to regenerate whole plants through in vitro regeneration of adventitious shoot buds from the transformed tissues [7-14]. This has prompted some workers to adopt non-tissue culture based approaches that do not depend on the regeneration of adventitious shoot buds for generating transgenic plants of peanut $[15,16]$. In general, the number of independently transformed plants obtained so far has been very low. Stable engineered resistance requires the production of numerous independent transformants to allow the selection of those with the appropriate level of gene expression [14]. For successful genetic modification by the production of transgenic plants, effective regeneration and transformation system is imperative.

The transformation protocol reported here was initially optimized by using marker genes (npt II; uidA) and later used for transforming with the coat protein gene of Indian peanut clump virus (IPCVcp) to induce resistance to this virus. The Indian peanut clump virus (IPCV; Pecluvirus) is widespread in India, where it causes clump disease in peanut crop [17]. Despite the screening of more than 10000 lines of peanut germplasm, no sources of resistance to IPCV have been found. IPCV is transmitted by Polymyxa gramminis, a soil-borne protozoan [18] and is difficult to control because of its persistence in soil for several years and the lack of suitable biocides or resistant genotypes. Transformation of plants with DNA encoding the coat protein and replicase genes of viruses is an efficient means to enhance the germplasm for resistance to viral diseases [19]. The coat protein gene of IPCV from its RNA-2 has been cloned and sequenced [20] and its expression in Nicotiana benthamiana studied [21]. At ICRISAT, attempts are underway to induce resistance to IPCV and other peanut viruses by using biotechnological tools. This study describes a protocol for efficient regeneration of multiple adventitious shoot buds from mature cotyledon explants of peanut and the production of fertile transgenic plants by $A$. tumefaciens-mediated transformation. The transformation system reported here is potentially applicable to a wide range of genotypes.

\section{Materials and methods}

\subsection{Tissue culture system}

Mature seeds from different peanut varieties were removed from mature pods and stored at $4^{\circ} \mathrm{C}$ for further use. Unless mentioned otherwise, variety JL-24 was used in all the experiments to optimize adventitious bud formation from cotyledon explants on various media formulations containing different concentrations of $N^{6}$-benzyladenine (BA; $2.5,5.0,7.5,10.0,15.0,20.0,25.0 \mu \mathrm{M})$ and $2,4-$ dichlorophenoxyacetic acid $(2,4-\mathrm{D} ; 1.0,2.5,5.0$, $7.5,10.0,15.0,20.0 \mu \mathrm{M})$ in $7 \times 7$ combinations. Five other peanut varieties belonging to two botanical types viz., Spanish and Virginia types (Table 1) were also used to test for shoot bud regeneration response on the optimized medium. Prior to use, the seeds were surface sterilized by rinsing in $70 \%$ ethanol for $1 \mathrm{~min}$ followed by treatment with $0.1 \%(\mathrm{w} / \mathrm{v})$ aqueous mercuric chloride for $10 \mathrm{~min}$ and then washed thoroughly four to six times with sterile-distilled water and soaked in sterile water for $2 \mathrm{~h}$ before use. After removing the seed coat, the embryo axis was removed surgically and each cotyledon was cut into vertical halves to obtain the cotyledon explants (Fig. 1A). The explants were placed on the shoot induction

Table 1

Effect of genotype on shoot regeneration from cotyledon explants of different varieties of A. hypogaea L.

\begin{tabular}{|c|c|c|c|c|}
\hline Variety & Botanical type & Number of explants cultured & Number of explants with shoots & Percent explants \\
\hline JL-24 (control) ${ }^{\mathrm{b}}$ & Spanish & 44 & 42 & 95.5 \\
\hline $\mathrm{J}-11$ & Spanish & 36 & 30 & 83.3 \\
\hline ICGS-11 & Spanish & 36 & 33 & 91.7 \\
\hline Robut-33-1 & Virginia & 44 & 43 & 97.7 \\
\hline ICGS-76 & Virginia & 40 & 32 & 80.0 \\
\hline ICGS-44 & Virginia & 44 & 38 & 86.4 \\
\hline
\end{tabular}

\footnotetext{
a Shoot induction medium (SIM), MMS +20- $\mu \mathrm{M} \mathrm{BA}+10-\mu \mathrm{M}$ 2,4-D; culture period, 4 weeks.
}

$\mathrm{b}$ The shoot induction medium (SIM) was originally optimized for variety JL-24. 

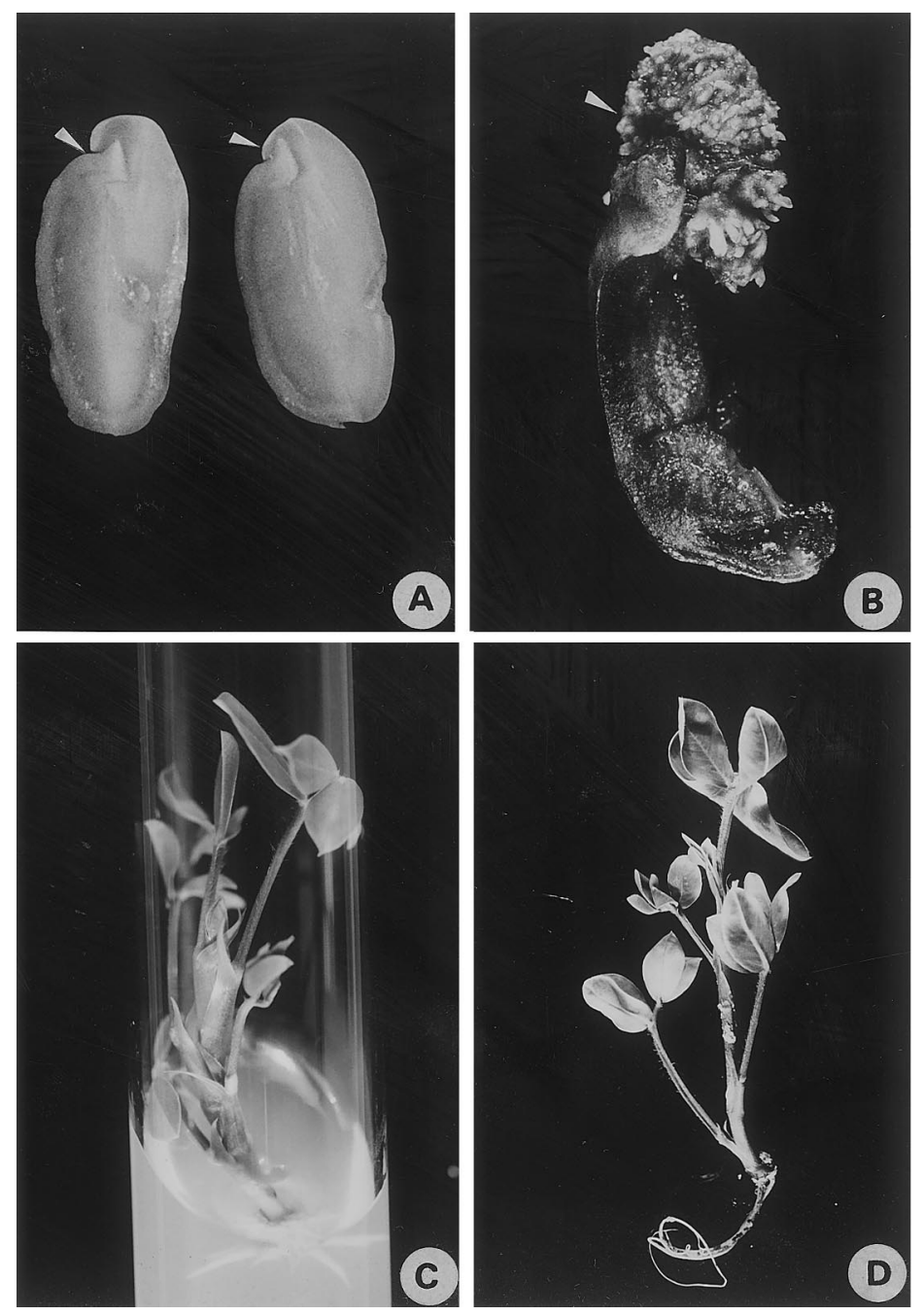

Fig. 1. Regeneration of adventitious shoots from cotyledon explants of A. hypogaea L. (A) Cotyledon explant at the time of culture initiation on shoot induction medium (SIM). Arrows indicate the proximal cut end with high regeneration potential. (B) Induction of adventitious shoot buds from cotyledon explants after 14 days of culture on SIM showing the formation of multiple shoot buds. Arrows indicate the proximal cut end having multiple shoot buds. (C) Production of multiple adventitious roots on elongated shoots after 14 days of culture on root induction medium (RIM). (D) Well-developed roots on an in vitro formed shoot after 28 days of culture on RIM showing normal adventitious roots suitable for transplantation to glasshouse.

medium (SIM) such that the cut edges were embedded into the medium. The SIM comprised of modified MS medium (MMS) containing MS inorganic salts [22], organic constituents [23], $3 \%$ sucrose at $\mathrm{pH} 5.8$ (adjusted before autoclaving) and solidified with $0.8 \%(\mathrm{w} / \mathrm{v})$ Difco Bacto agar in $100 \times 25 \mathrm{~mm}$ sterile petri dishes. Modified MS (MMS) medium was supplemented with $20 \mu \mathrm{M}$ BA and $10 \mu \mathrm{M}$ 2,4-D prior to autoclaving. The explants were plated at a density of five cotyledons per petri dish and sealed with parafilm. All the cultures were incubated at $26 \pm$ $1^{\circ} \mathrm{C}$ under continuous light of $100 \mu \mathrm{Es}^{-1} \mathrm{~m}^{-2}$ irradiance provided by cool daylight fluorescent lamps.
The explants were transferred to shoot elongation medium containing MMS with $2 \mu \mathrm{M}$ BA (SEM) for two to three passages of 28 days each for the development and elongation of adventitious shoot buds. The elongated shoots were transferred to root induction medium (RIM) comprising of MMS containing $5 \mu \mathrm{M} \alpha$-naphthaleneacetic acid (NAA) for 28 days, and then the plants were transplanted to autoclaved sand-soil (1:1) mixture in plastic pots. The plants were maintained in a growth cabinet at $25 \pm 1^{\circ} \mathrm{C}$ with $85 \%$ relative humidity for 2 week prior to their transfer to a greenhouse in 12-in. (diameter) pots containing autoclaved field soil. The plants were irrigated with Hoagland's nutrient solution once a month and routinely irrigated with tap water. 


\subsection{Plasmid constructs}

Plasmid pBI121 (13 kb; Fig. 2A) containing the uid $\mathrm{A}(G U S)$ as reporter gene linked to the CaMV $35 \mathrm{~S}$ promoter and NOS terminater and $n p t$ II gene under the control of a nopaline synthase (NOS) promoter and terminater was used for initial optimization [24]. The plasmid pROKII:IPCVcp (Fig. 2B; kindly provided by Dr Mike Mayo, Scottish Crop Research Institute, Dundee, UK), contains the coat protein gene of the Indian peanut clump virus (IPCVcp). The plasmid pROKII:IPCVcp contains coat protein gene having $600 \mathrm{bp}$ untranslated $5^{\prime}$ region followed by 650 -bp coding region driven by a CaMV $35 \mathrm{~S}$ promoter and NOS terminator and chimeric $n p t$ II gene under the control of NOS promoter and terminater within the T-DNA borders. Both these plasmids contain kanamycin resistance gene for bacterial selection. Plasmid pRT99gus:IPCVcp was constructed by cloning the HindIII fragment of plasmid pRTL2:IPCVcp (carrying the IPCVep ORF driven by a double $35 \mathrm{~S}$ promoter, tobacco etch virus (TEV) leader and terminated by $35 \mathrm{~S}$ poly A signal) into the HindIII site of plasmid pRT99gus [25] that has npt II and uidA genes. Thus plasmid pRT99gus:IPCVcp contains $n p t \mathrm{II}$, uidA and IPCV coat protein gene for expression in plant tissues and ampicillin resistance for bacterial expression.

\subsection{Transformation procedure}

Disarmed $A$. tumefaciens strain C58, harboring binary plasmids pBI121 or pROKII:IPCVcp were used for transformation. Both plasmids specify the kanamycin resistance in the host bacteria while the A. tumefaciens strain $C 58$ also has resistance to rifampicin. Thus, the strains were maintained on LB [26] agar plates containing $50 \mu \mathrm{g} \mathrm{ml} \mathrm{ml}^{-1}$ kanamycin and $25 \mu \mathrm{g} \mathrm{ml}{ }^{-1}$ rifampicin. Single colonies of the individual strain were grown overnight at $28^{\circ} \mathrm{C}$ in $20 \mathrm{ml}$ of YEB [26] supplemented with appropriate antibiotics. Bacterial suspension $(5 \mathrm{ml})$ was pelleted by centrifugation for $10 \mathrm{~min}$ at $5000 \mathrm{rpm}$ and resuspended the cells in $30 \mathrm{ml}$ of $1 / 2$ strength MS-containing 3\% sucrose (1:6 dilution). This suspension was stored at $4^{\circ} \mathrm{C}$ for $1-2 \mathrm{~h}$ and used for co-cultivation. The bacterial suspension was poured in a sterile petri plate so as to make a thin film $(2-3 \mathrm{~mm})$ at the base of the petri plate. Freshly excised cotyledon explants from peanut variety JL-24 were taken and their proximal cut ends (Fig. 1A) were immersed into the bacterial suspension for few seconds and immediately implanted on SIM with the proximal cut ends embedded in the medium as mentioned above. The cotyledons were co-cultivated with the Agrobacterium for $72 \mathrm{~h}$ and transferred to SIM supplemented with filter-sterilized cefotaxime (250 $\mu \mathrm{g} \mathrm{ml}^{-1}$ ) and again care was taken to embed their cut ends into media. Plating density was maintained at five explants per plate.

\subsection{Plant regeneration and selection of stable transformants}

The cotyledon explants after treatment with Agrobacterium were maintained on SIM contain-

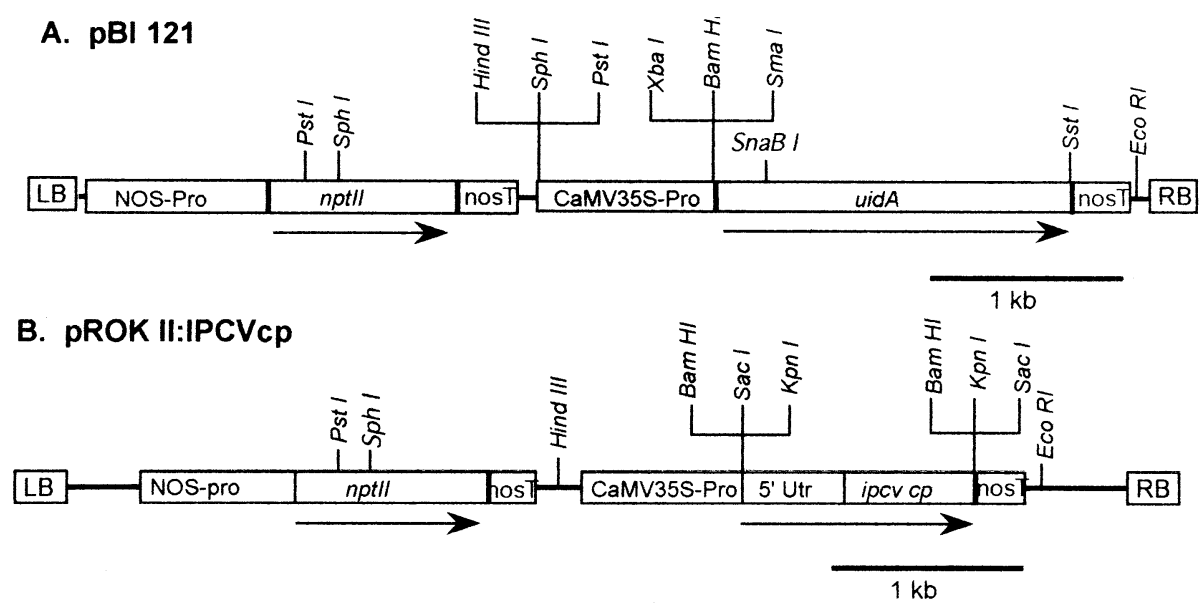

Fig. 2. T-DNA regions of the binary plasmids used for $A$. tumefaciens-mediated transformation. (A) Plasmid pBI121 containing $n p t$ II and uidA genes. (B) Plasmid pROK II:IPCVcp containing $n p t$ II and IPCVcp genes, (LB, left border; RB, right border; nptII, neomycin phosphotransferase; IPCVcp, coat protein gene of Indian peanut clump virus). 
ing filter-sterilized $250 \mu \mathrm{g} \mathrm{ml}{ }^{-1}$ cefotaxime for 2 weeks when multiple shoot buds appeared on at least $70 \%$ of the explants while shoot buds continue to form. At this stage, the explants bearing shoot buds were transferred to SIM containing $250 \mu \mathrm{g} \mathrm{ml}^{-1}$ cefotaxime and $125 \mu \mathrm{g} \mathrm{ml}-1$ kanamycin to initiate selection and enrichment of transformed cells, organogenic tissues differentiated shoot buds for another 2 weeks. Subsequently, proximal parts of the explants containing multiple adventitious shoot buds were excised and transferred to SEM containing $125 \mu \mathrm{g} \mathrm{ml}-1$ kanamycin for two to three subcultures of 4-week duration each. After this stage, the elongated shoots $(3-4 \mathrm{~cm})$ were cultured on RIM without any antibiotic for rooting of the elongated shoots. All the shoots that were cultured on RIM produced multiple adventitious roots within about 2 weeks.

\subsection{Cultivation of putative transgenic plants}

The rooted shoots were transferred to pots containing autoclaved sand and soil (1:1) mixture and maintained under high humidity $(85 \%)$ at $25^{\circ} \mathrm{C}$ in a growth cabinet. After 2 weeks, they were transferred to the glasshouse and allowed to flower and set seed. Upon flowering ( 2 months after transplantation), and pod formation (within 4 months) the mature seeds were collected and analyzed for the presence and expression of the introduced genes. The primary transformants upon transfer to the containment glasshouse were termed as T0 generation while those from subsequent seed generations were termed as \# T1, \# T2, \# T3, and so on.

\subsection{Histochemical analysis of putative transformants}

$\beta$-Glucuronidase ( $G U S$ ) enzyme activity was detected histochemically in unfixed leaves and freehand sections of petiole and stem sections of regenerated plants growing in vitro on $125 \mu \mathrm{g}$ $\mathrm{ml}^{-1}$ kanamycin-containing medium or in the containment glasshouse by using X-gluc (5-bromo4-chloro-3-indolyl- $\beta$-glucuronide) as the substrate [24]. After the histochemical reaction at $37^{\circ} \mathrm{C}$ for $6-12 \mathrm{~h}$ the tissue was cleared in $70 \%$ ethanol and examined.

\subsection{Molecular analysis}

Total genomic DNA was isolated from fresh leaves of in vitro or glasshouse-growing putative transformants (T0 and T1 generations). Leaf tissue (1 g) was ground in liquid nitrogen with a mortar and pestle by following the method based on Dellaporta et al. [27] with some modifications. The ground fine leaf powder was transferred into 30-ml centrifuge tube and $15 \mathrm{ml}$ of extraction buffer was added before thawing of the tissue. The contents were mixed well by inverting the tubes five to six times and $1 \mathrm{ml}$ of $20 \% \mathrm{SDS}$ was added prior to incubation at $65^{\circ} \mathrm{C}$ for $10 \mathrm{~min}$. Five mililitres of $5 \mathrm{M}$-potassium acetate was added to the extract and incubated at $-20^{\circ} \mathrm{C}$ for $20 \mathrm{~min}$. The supernatant was collected after centrifugation and the DNA was precipitated with isopropanol and centrifuged at $10000 \mathrm{rpm}$ to collect the DNA pellet. The pellet was washed with ice-cold $70 \%$ ethanol, air-dried and dissolved in $10 \mathrm{mM}$ Tris, $\mathrm{pH}$ 8.0. After treatment with ribonuclease A (RNase A) the DNA was resuspended in DEAE-cellulose (Whatman DE52) suspension to remove the polysaccharides and proteins followed by purification [28].

\subsubsection{PCR analysis of putative transformants}

Putative transformants were screened by polymerase chain reaction (PCR) for the presence of $n p t$ II and IPCVcp genes for routine analysis. The 700 -bp region of $n p t$ II was amplified by using 22-mer oligonucleotide primers as previously reported [29]. A 585-bp coding region of the IPCVcp gene was amplified by using 21-mer oligonucleotide primers (IPCVcp primer I:5'-AGT TAC TCG TGG TGG TGG TCA-3'; and IPCVep primer II:5'-GGA GTG GCC GCT GGA TTA GGG-3'). The amplification reactions were carried out by using a Techne ${ }^{\mathrm{TM}}$ PHC3 thermal cycler under the following conditions $-94^{\circ} \mathrm{C}$ for $4 \mathrm{~min}$ (one cycle), $92^{\circ} \mathrm{C}$ for $60 \mathrm{~s}$ (denaturation), $52^{\circ} \mathrm{C}$ for $45 \mathrm{~s}$ (annealing), $72^{\circ} \mathrm{C}$ for $90 \mathrm{~s}$ (extension) for 28 cycles and final extension at $72^{\circ} \mathrm{C}$ for 5 min (one cycle). The PCR was performed by using $\sim 200 \mathrm{ng}$ of purified genomic DNA and the recombinant Taq DNA polymerase (Gibco-BRL) according to manufacturer's recommendations. The amplified products were assayed by electrophoresis on $1.2 \%$ agarose gels. To verify the fidelity of the amplicons, the fragments resolved on the agarose gels 
were transferred to Hybond + nylon membranes (Amersham) by Southern blotting [26] and probed with $n p t$ II or IPCVcp fragments from the respective plasmids (Fig. 2). The blots were hybridized with the PstI fragment containing 800-bp coding sequence of $n p t \mathrm{II}$ gene or Bam $\mathrm{HI}$ fragment containing 1200-bp coding sequence of IPCVcp from pROKII:IPCVcp labeled with non-radioactive AlkPhos direct system ${ }^{\mathrm{TM}}$ (Amersham).

\subsubsection{Southern blot analysis}

For Southern hybridization analysis, the genomic DNA $(10-15 \mu \mathrm{g})$ from each of the putative transformants was separately digested with Bam HI that has two restriction sites in the pROKII:PCVep or HindIII that has a single internal site in pBI121 and pROK II:IPCVcp (Fig. 2) to ascertain the integration pattern based on size separation and the number of copies of insert DNA. The digested DNA was run on $0.8 \%$ agarose gels to separate the DNA fragments that were transferred onto nylon membranes (Hybond $\mathrm{N}+$, Amersham) using standard protocols [26]. PCR amplified fragments of respective coding sequences (700 bp of $n p t$ II and $585 \mathrm{bp}$ of IPCVcp) were used as probes after labeling with non-radioactive AlkPhos direct system (Amersham). The labeling, hybridization and detection methods were performed according to the manufacturer's instructions.

\section{Results}

\subsection{Shoot bud differentiation}

In preliminary studies, the cotyledon explants (Fig. 1A) from mature seeds of peanut variety JL-24 were cultured on different media formulations containing varying concentrations of BA. Amongst the different media tested MMS containing $20 \mu \mathrm{M}$ BA and $10 \mu \mathrm{M}$ 2,4-D (shoot induction medium; SIM) produced the highest frequency $(95.5 \%)$ of multiple adventitious shoot buds. The whole cotyledons also underwent regeneration at similar high frequencies (data not shown), but the number of shoots per responding explant was much higher when the cotyledons were split in vertical halves (Fig. 1A). Each half of the split cotyledon responded with similar frequencies while producing greater number of adventitious shoot buds per explant (Fig. 1B). On SIM, the six peanut varieties produced shoot buds with high frequencies $(80.0-97.7 \%)$ and followed a similar pattern of growth and development (Table 1). Variety JL-24 was used in all the experiments on the optimization of genetic transformation although recently, the experiments are also being carried out on variety ICGS-44 with similar results.

On SIM, the explants turned green and underwent considerable enlargement within 3 days of culture initiation. On these explants, multiple shoot buds differentiated at the proximal cut end (Fig. 1B) within 14 days in over $90 \%$ of the explants. However, no further elongation of the shoot buds occurred even after 4 weeks on SIM. Hence, the explants bearing shoot buds were cut into two to four pieces and transferred on to MS medium containing $2 \mu \mathrm{M}$ BA (shoot elongation medium; SEM) for at least three passages of 4 week each when elongated shoots were rescued at the end of each passage. Frequently, four to eight shoots were recovered from each explant although over ten shoots could be recovered if the explants were subcultured on SEM for two to three extra subcultures. However, an important consideration for a high frequency of adventitious shoot bud regeneration is that the proximal cut end should be embedded into the medium so that it remains in contact with the medium at least for the first 2 week of culture initiation.

The shoots were micropropagated on SEM through nodal explants for clonal multiplication and eventually rooted on MS medium containing $5 \mu \mathrm{M}$ NAA. The adventitious roots appeared within 2 weeks (Fig. 1C) and developed further in 4 weeks (Fig. 1D) when the plants were ready for transplantation to pots. All the rooted shoots ( $>$ 95\%) survived after transplantation and appeared phenotypically normal. In the glasshouse, all the transformed plants produced flowers and pods within 4 months and these contained viable seeds. Each plant produced up to 40 pods that provided a total of up to 75 seeds per plant when grown in 12-in. pots.

\subsection{Genetic transformation}

Following the protocol mentioned above, the cotyledon explants (Fig. 1A) of variety JL-24 were used for initiating experiments on genetic transfor- 
mation. The explants were co-cultivated with Agrobacterium for $72 \mathrm{~h}$. Pre-culture of the explants on hormone-free MMS or SIM for $24 \mathrm{~h}$ did not have any beneficial effect. After 4 weeks of incubation on the selection medium containing SIM with $250 \mu \mathrm{g} \mathrm{ml} \mathrm{ml}^{-1}$ cefotaxime and $125 \mu \mathrm{g} \mathrm{ml}-1$ kanamycin, some of the regenerated shoots (Fig. 1B) underwent bleaching, but it was not considered very reliable for visual selection since some of the non-bleaching shoots were found to be untransformed. Regenerating explants could survive very high levels of kanamycin (up to $200 \mu \mathrm{g}$ $\mathrm{ml}^{-1}$ ). Although multiple shoots were formed on $72 \%$ of the explants, apparent bleaching was observed in less than $50 \%$ of the shoots. This observation suggests that in peanut though kanamycin did not result in efficient visual selection of the transformants, it did play a selective role on the suppression of shoot bud induction from the untransformed cells of the explants. This was also observed during GUS histochemical and PCR analysis where over $50 \%$ of the randomly selected shoots tested positive. Other analogs of kanamycin, i.e. paromomycin and geniticin, were also used for comparisons but none of these provide any distinct advantage over kanamycin (data not shown). The rooted shoots (Fig. 1D) were transplanted first under high relative humidity of $80 \%$ for 10 days and later to glasshouse where $100 \%$ of the shoots survived. Over 100 independently transformed putative transgenic plants were maintained in the glasshouse for further analysis. Transgenic plants appeared phenotypically normal and set viable seeds. To date, no apparent undesirable genetic change due to tissue culture or transformation process has been observed in the glasshouse grown plants. This procedure has been tested with variety ICGS-44 for transformation responses and a large number of putatively transformed shoots were rescued. Moleular tests have confirmed their transgenic status (data not shown).

\subsection{Characterization of transgenic plants}

Each putative independent transformant arising from a treated explant was numbered at the time of isolation and separately maintained for subsequent DNA analysis and progression of generation. All the seeds collected from an individual transformant were suitably dried and stored at $5-10^{\circ} \mathrm{C}$ until further use. So far in excess of 75 independently transformed plants have successfully been transplanted to the glasshouse and their T1 generation seed collected. About 40 of these have been advanced to the T2 generation. Transformed plants, which were obtained by using the plasmid pBI121 and selected on $125 \mu \mathrm{g} \mathrm{ml}-1$ kanamycin, were identified in the T0 generation (primary transformants) putatively by using GUS expression in the leaflets and petiole and stem cross sections. $\beta$-Glucuronidase (GUS) expression in the $\mathrm{T} 1$ generation progeny confirmed the segregation of uidA gene in a Mendelian ratio of 3:1 (i.e., 15 out of 21 randomly selected plants from the progeny of transformant \# 1R1 tested positive for GUS expression in histochemical analysis).

Oligonucleotide primers specific to the coding regions of $n p t$ II and IPCVcp genes amplified the expected size of the respective gene fragments from at least $70 \%$ of the analyzed putative transformants (Fig. 3A and Fig. 4A, B). PCR analysis was performed on the genomic DNA of the transformants obtained with plasmid pBI121. Fig. 3A shows the amplification of $n p t$ II gene in randomly selected transformants of $\mathrm{T} 1$ generation that originated from four cotyledon explants where the negative plants (lanes 3 and 10) were due to segregation of the negative allele. To determine the authenticity of PCR products, the amplicons were transferred to nylon membrane where they showed positive Southern hybridization with the npt II gene probe. Southern hybridization analysis was performed on 14 of these plants to assay the presence and copy number of pBI121 T-DNA. The results on presence of the npt II gene in PCR analysis as shown in Fig. 3A were confirmed by Southern hybridization (Fig. 3B). In addition, the results in Fig. 3B also showed that all the selected plants were independent transformants that resulted from independent integrations. Eight of the ten positive transformants $(80 \%)$ possessed a single copy insert whereas two $(20 \%)$ had two copies. Occasionally, transformants showing multiple inserts ranging from three to five copies were also observed. An interesting feature of the integration pattern of $n p t$ II gene is that multiple plants originating from a single explant were due to independent transformation events (see Fig. 3B, lanes 1-4; $6-8 ; 11-14)$ suggesting the high efficiency of the cotyledon system. A similar pattern was also noted for uidA gene (data not shown) indicating that the 


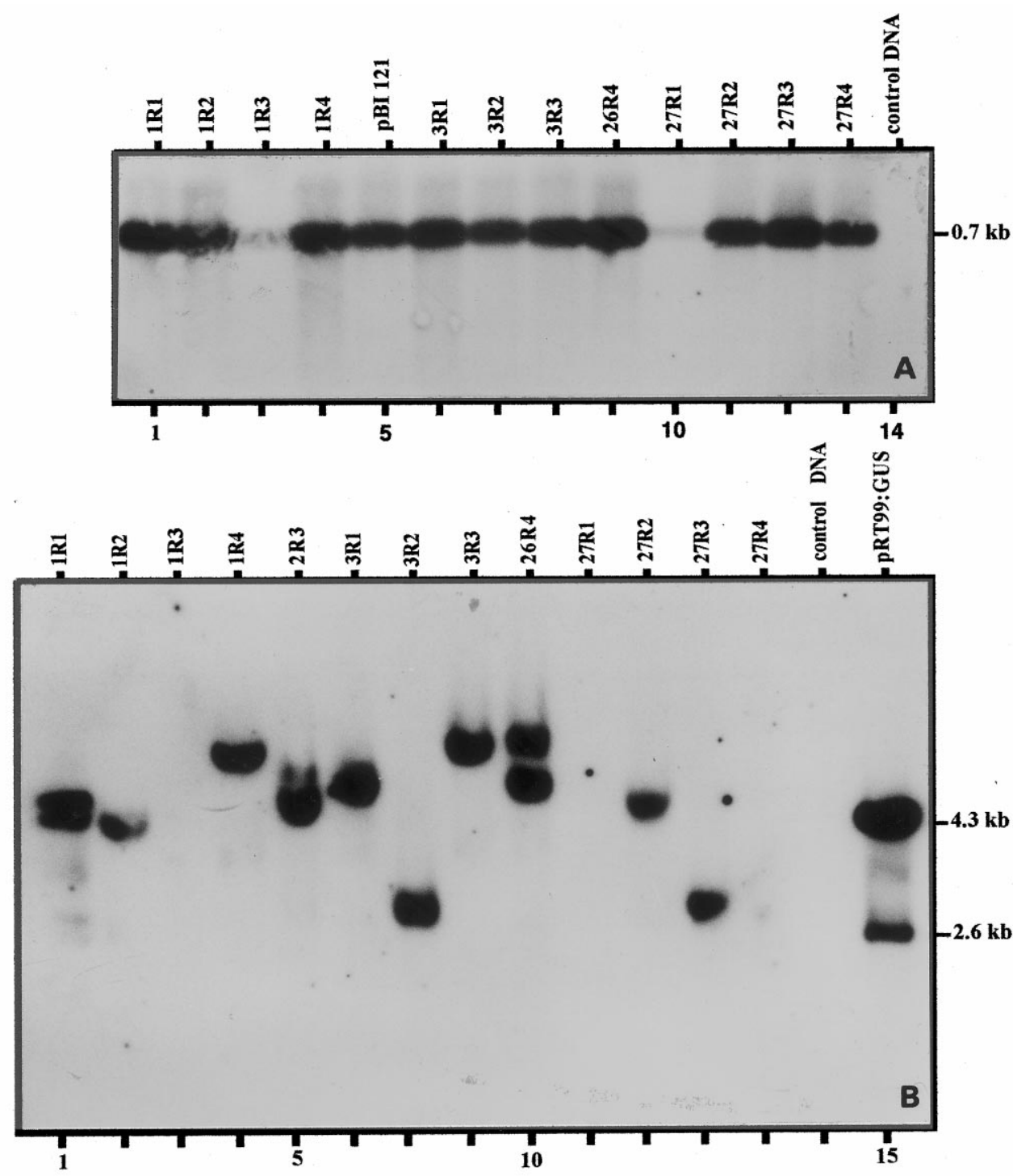

Fig. 3. Molecular analysis of $n p t \mathrm{II}$ gene in the genomic DNA of T1 generation of peanut plants transformed with the plasmid pBI121 based in A. tumefaciens strain C58. (A) PCR amplification of 700-bp fragment of npt II coding region. The PCR products were resolved on $1.2 \%$ agarose gels and probed with non-radio Alkphos-labeled $n p t$ II gene $(0.8-\mathrm{kb}$ Pst I fragment of the plasmid pBI121) by Southern hybridization. (B) Southern blot analysis of $n p t$ II gene. The DNA was digested with HindIII to provide a single restriction within the T-DNA. The blot was probed with non-radio Alkphos-labeled 700-bp PCR amplified npt II gene fragment.

$n p t \mathrm{II}$ and uidA genes co-segregated in the T1 generation progeny.

The binary plasmid pROKII:IPCVep having $n p t \mathrm{II}$ and the coat protein gene of Indian peanut clump virus (IPCVcp) based in A. tumefaciens strain $C 58$ was used to obtain transgenic plants from cotyledon explants. From the T0 and T1 generation, plants growing in the glasshouse putative transformants were randomly selected for PCR amplification of $n p t$ II and IPCVcp gene fragments from the genomic DNA. To ascertain the fidelity of amplifications in PCR reaction, the
PCR products were transferred to nylon membranes for Southern hybridization and probed with non-radio labeled fragments of the respective genes from the plasmids shown in Fig. 2. Transgenic nature of all the selected plants was confirmed by the expected amplification of the respective genes (Fig. 4A, B). All the selected samples of the progeny of plant \# PCV 24 (lanes 6-13) showed positive amplification for both $n p t \mathrm{II}$ and IPCVcp genes and five other independently transformed plants were also positive for these genes. 
Randomly selected plants from T0 and T1 generations growing in the glasshouse were selected for Southern hybridization to ascertain the integration and copy number of the $n p t$ II and IPCVcp genes. Genomic DNAs of 17 putative transformants obtained after transformation with the plasmid pROKII:IPCVcp were restricted with HindIII that restricts the T-DNA only once. To maintain uniformity of observations the blot was initially hybridized with the nptII gene probe and then rehybridized with the IPCVcp gene probe after stripping the $n p t$ II probe. Apparently the stripping of $n p t$ II probe was not complete that resulted in some overlap (Fig. 5B). However, a similar pattern of integration of both $n p t$ II and IPCVcp genes was evident. From the 17 selected plants, four plants from the segregating generation were negative (lanes 5, 11, 13, 15). The remaining 13 plants showed positive hybridization for both $n p t$ II (Fig. 5A) and IPCVep (Fig. 5B) genes. Two plants showed the integration of two copies (lanes 2 and 8) while the rest carried single inserts. Rarely plants with more than two and up to five integrations were also observed but the frequency of such plants was less than $5 \%$ of the total transformants. Interestingly, all the positively transformed plants exhibited distinct patterns of gene integration suggesting the origin of plants as a result of independent transformation events. The two genes co-segregated in the $\mathrm{T} 1$ progeny plants. To ascertain the inheritance pattern of the introduced genes, genomic DNA from 35 plants of T1 proge-

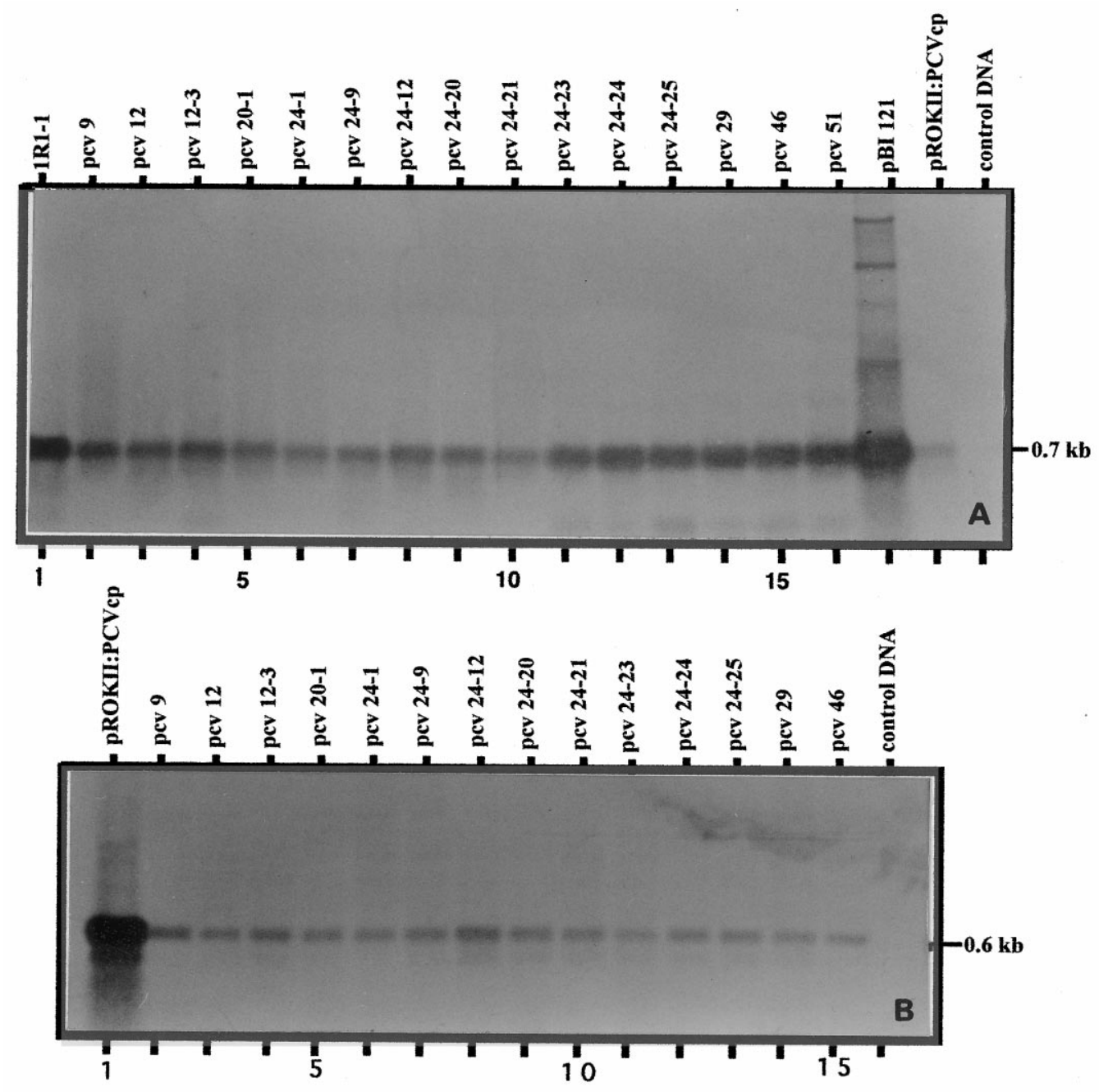

Fig. 4. PCR analysis of $n p t$ II and IPCVcp genes from the genomic DNA of peanut plants transformed with plasmid pROK II:IPCVcp showing the amplification of 700-bp (A) and 585-bp (B) fragments of $n p t$ II and IPCVcp genes respectively. The PCR products were resolved on $1.2 \%$ agarose gels and probed with non-radio Alkphos-labeled $n p t$ II $(0.8-\mathrm{kb}$ Pst I restricted fragment of the plasmid pBI121) and IPCVcp (1.2-kb BamHI restricted fragment of the plasmid pROKII:IPCVcp) gene fragments by Southern hybridization. 


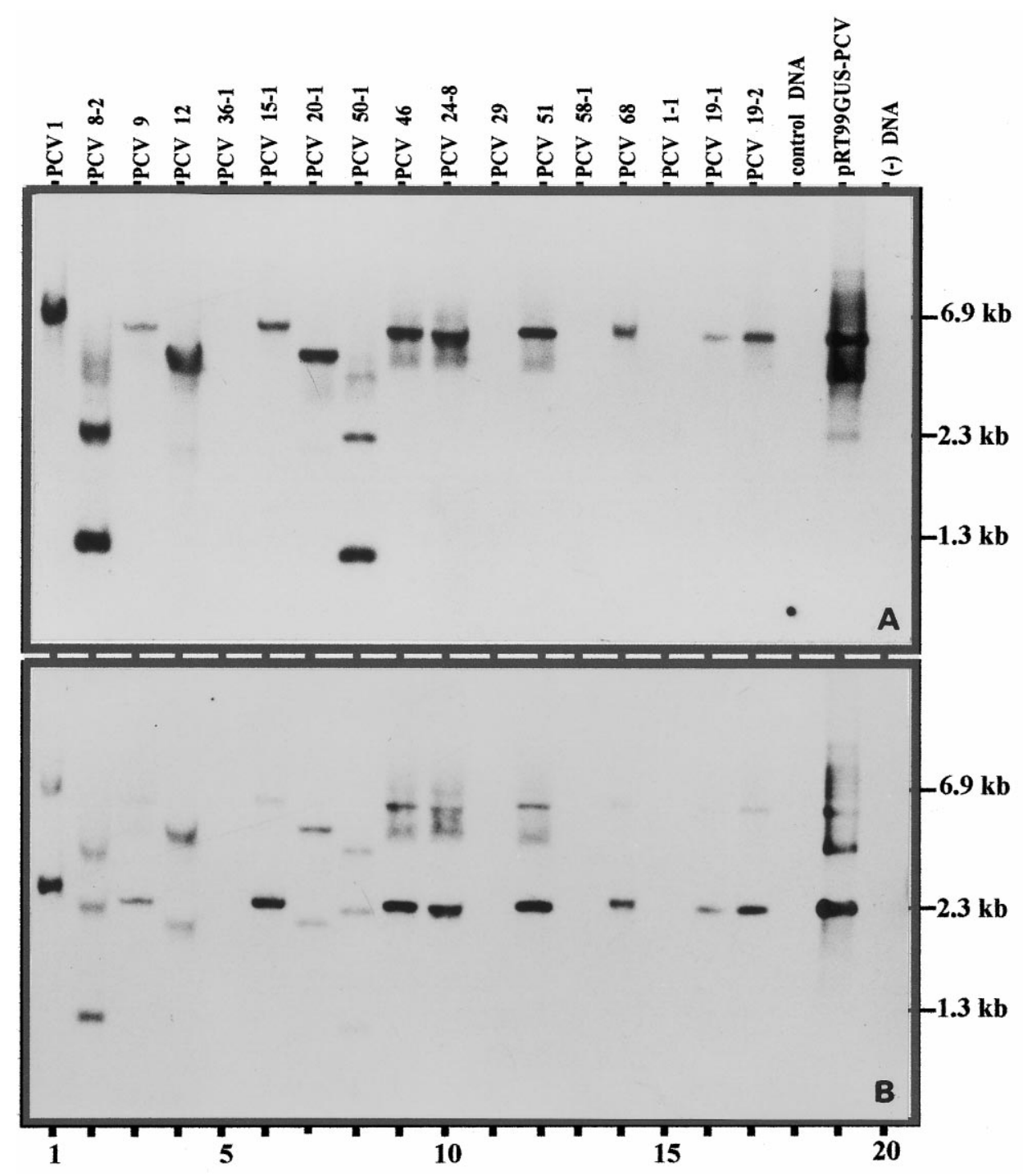

Fig. 5. Southern blot analysis of $n p t I I$ (A) and IPCVcp (B) genes in the genomic DNA of peanut plants transformed with $A$. tumefaciens carrying the binary plasmid pROK II:IPCVcp. The DNA was restricted with HindIII to provide a single restriction within the T-DNA. The blots were probed with non-radio Alkphos-labeled PCR amplified fragment of $n p t$ II (700 bp) and IPCVcp (585 bp) genes, respectively.

nies of one transformant (plant \# PCV 24) that has a single copy integration of IPCVcp gene was processed for Southern hybridization after restriction with HindIII. As expected, a single-copy integration was observed in about $75 \%$ of the plants (data not shown) suggesting the segregation in 3:1 Mendelian ratio that is characteristic of a single locus trait.

\section{Discussion}

Several methods have earlier been reported to yield transgenic peanut plants that are in general labor-intensive or often inefficient [8,10-16,30]. A comparison of different procedures for transformation of $A$. hypogaea indicates wide variations in transformation efficiencies as measured by shoot regeneration and yield of transformed shoots. The biolistic-based systems for gene delivery into embryogenic calluses and embryo axes is labor intensive and requires the bombardment of a large number of explants to obtain a few transformed cell lines $(1 \%)$ which produce transgenic plants at low frequencies that are often chimeric or result from a few transformation events [8]. To date, the A. tumefaciens-based gene delivery systems have resulted in a limited success due to inefficient 
shoot regeneration from the selected peanut explants. Although the reported methods using $A$. tumefaciens yielded a large percentage of shoot regeneration and numerous transformed calluses, the percentage of confirmed transformed plants was either not presented or varied between $\sim 0.3$ and $9.0 \%[10,11,15,16]$. A non-tissue culture based approach that does not rely upon adventitious shoot regeneration by utilizing peanut embryos to generate transgenic plants (in plant transformation) has been adopted to overcome the problems associated with inconsistencies in in vitro shoot regeneration responses $[15,16]$. However, such methods are of limited use because they require high inputs in terms of the number of treatments to obtain very small number of independent transformants. In addition, such approach is labor intensive requiring vir gene induction treatments such as the use of wounded tobacco leaf extract to enhance the transformation efficiency of $A$. tumefaciens. For example, only three independent transformation events involving 150 embryos resulted in 2\% transformation frequency [16] that often result in high degree of chimeric shoots where only a sector of T0 transformant may contain the T-DNA [15]. As a result, the use of peanut as a model system for gene expression studies has not been widely exploited. Hence, the method reported here is a significant improvement over the previously reported results on peanut transformation where at least $55 \%$ of the treated explants resulted in one or more independently transformed shoot.

The value of Agrobacterium-mediated plant transformation is measured primarily by the number of independently transformed plants carrying the gene of interest per explant used. This can be a function of genotype of the species to be transformed, the Agrobacterium strain (virulence), the selectable marker, regeneration capacity of the target cells, and the accessibility of the bacterium to the regenerable cells [31]. An additional, lessfrequently quantified variable is the amount of labor required to maintain cultures until transformed shoots are obtained. The transformation procedure utilizing cotyledon explants reported here is both highly susceptible to Agrobacteriummediated gene transfer and also displays very high regeneration rates across a wide range of $A$. hypogaea varieties, often with numerous independently transformed shoots per explant. The manipula- tions used were simple as compared with several previously reported systems. An important aspect of this procedure is that multiple shoots are formed from a single explant. However, we have scored an explant as having a score of ' 1 ' whether a single or multiple shoots were produced. These multiple shoots from individual explants are often due to independent transformation events at the surface, which has been confirmed by histological investigations (K.K. Sharma, unpublished data). Considering this observation and data on molecular characterization, in which shoots originating from a single explant showed different integration pattern, the transformation frequency (in terms of number of shoots recovered from a single transformation experiment), in fact, may be much higher than $55 \%$.

The target cells for transformation in our experiments were those at the proximal cut surfaces of the cotyledon explants as has previously been shown in Brassica napus [32] which has resulted in very high levels of transformation frequencies [31]. The shoot development is very rapid (2-3 weeks) and the cut surface is an ideal target for Agrobacterium-mediated transformation as the cells undergoing organogenesis are those most readily accessed by the Agrobacterium. A key feature of this procedure is the regenerability of the cells wounded during excision of the cotyledons and these cells are mainly surface cells, readily accessible to the bacterium. This observation was also confirmed by relatively low levels of regeneration and transformation frequencies that we obtained when intact de-embryonated cotyledons were used as explants as compared with the split cotyledon explant.

Cotyledon explants have been shown to be excellent explants for transformation and regeneration of fertile plants in several other crop species including B. napus [31] where kanamycin has been shown to be very effective in the selection of putative transformants. As reported previously [33], preculture of inoculated explants for two weeks in the absence of selection was important for enhanced efficiency of transformation although absence of selection at initial stages may also result in very low recovery of transformants [34]. However, judicious choice of selection levels may be an important criterion for the recovery of transformed cells, because too high a level would be deleterious even to the transformed cells at 
initial stages of screening. In the present study also, kanamycin selection was beneficial in producing transgenic plants from cotyledon explants when applied after 2 weeks of cocultivation. Kanamycin even at even high levels of $200 \mu \mathrm{g}$ $\mathrm{ml}^{-1}$ restricted but not always completely inhibited regeneration from control cotyledon explants and did not produce the bleaching effect which is typical of kanamycin on plant tissue cultures. However, kanamycin selection did enrich the growth of transformed tissue in shoot forming cotyledon explants since the proportion of positively transformed plants was very high amongst randomly selected putative transformants.

In conclusion, the cotyledon regeneration system proved to be an excellent vehicle for the production of a large number of transgenic peanut plants over relatively short periods. In addition, this explant allowed Agrobacterium-mediated transformation to be targeted to regeneration competent tissue. Shoot formation was rapid and prolific, and a large proportion of these shoots developed into phenotypically normal fertile plants. Some of the transformed plants reported here have been positively tested for gene expression in RT-PCR and Northern hybridization studies (data not shown). This protocol is genotype-independent and provides a transformation scheme that allows cost-effective, routine use of peanut transformation as part of basic studies in gene expression. The development of genetically transformed peanut cultivars with resistance to viruses and other biotic constraints should have tremendous impact on crop productivity especially in the resource-poor agricultural systems of the semi-arid tropics.

\section{Acknowledgements}

We greatfully acknowledge the technical assistance of M. Lavanya, D. Pandary and Jagan Mohan Reddy, and assistance of L. Vidyasagar with photography. Dr R. Ortiz, Dr S. Sivaramakrishnan and Dr N. Seetharama provided useful suggestions on the manuscript. We thank Dr Mike Mayo, Scottish Crops Research Institute, for providing plasmid pROKII:IPCVcp, and his constant encouragement. Part of the funding for this work was provided by grants from OPEC and Asian Development Bank.

\section{References}

[1] K.K. Sharma, R. Ortiz, Program for the application of genetic transformation for crop improvement in the semi-arid tropics, In Vitro Cell. Dev. Biol.-Plant 36 (2000), in press.

[2] H.T. Stalker, J.P. Moss, Speciation, cytogenetics, and utilization of Arachis species, Adv. Agron. 41 (1987) $1-40$.

[3] M. Cheng, D.C.H. Hsi, G.C. Phillips, In vitro regeneration of Valencia-type peanut (Arachis hypogaea L.) from cultured petiolules, epicotyl sections and other seedling explants, Peanut Sci. 19 (1992) 82-87.

[4] Z. Li, R.L. Jarret, R.N. Pittman, J.W. Demski, Shoot organogenesis from cultured seed explants of peanut (Arachis hypogaea L.) using thidiazuron, In Vitro Cell. Dev. Biol. 30P (1994) 187-191.

[5] M. Kanyand, C.M. Peterson, C.S. Prakash, The differentiation of emergences into adventitious shoots in peanut, Arachis hypogaea (L.), Plant Sci. 126 (1997) 87-95.

[6] P. Venkatachalam, N. Geetha, A. Khandelwal, M.S. Shaila, G. Lakshmi Sita, Induction of direct somatic embryogenesis and plant regeneration from mature cotyledon explants of Arachis hypogaea L, Curr. Sci. 77 (1999) 269-273.

[7] C. Lacorte, E. Mansur, B. Timmerman, A.R. Cordeiro, Gene transfer into peanut (Arachis hypogaea L.) by Agrobacterium tumefaciens, Plant Cell Rep. 10 (1991) 354-357.

[8] P. Ozias-Akins, J.A. Schnall, W.F. Anderson, C. Singsit, T.E. Clemente, M.J. Adang, A.K. Weissinger, Regeneration of transgenic peanut plants from stably transformed embryogenic callus, Plant Sci. 93 (1993) 185-194.

[9] M. Cheng, D.C.H. Hsi, G.C. Phillips, Recovery of transformants of Valencia-type peanut using Agrobacterium tumefaciens, Peanut Sci. 21 (1994) 84-88.

[10] M. Cheng, R.L. Jarret, Z. Li, A. Xing, J.W. Demski, Production of fertile transgenic peanut (Arachis hypogaea L.) plants using Agrobacterium tumefaciens, Plant Cell Rep. 15 (1996) 653-657.

[11] S. Eapen, L. George, Agrobacterium tumefaciens mediated gene transfer in peanut (Arachis hypogaea L.), Plant Cell Rep. 13 (1994) 582-586.

[12] D.M. Livingstone, R.G. Birch, Plant regeneration and microprojectile-mediated gene transfer in embryonic leaflets of peanut (Arachis hypogaea L.), Aust. J. Plant Physiol. 22 (1995) 585-591.

[13] C. Singsit, M.J. Adang, R.E. Lynch, W.F. Anderson, A. Wang, G. Cardineau, P. Ozias-Akins, Expression of a Bacillus thuringiensis cryIA(c) gene in transgenic peanut plants and its efficiency against lesser cornstalk borer, Transgenic Res. 6 (1997) 169-176.

[14] H. Yang, C. Singsit, A. Wang, D. Gonsalves, P. OziasAkins, Transgenic peanut plants containing a nucleocapsid protein gene of tomato spotted wilt virus show divergent levels of gene expression, Plant Cell Rep. 17 (1998) 693-699.

[15] A.H. McKently, G.A. Moore, H. Doostdar, R.P. Niedz, Agrobacterium-mediated transformation of peanut 
(Arachis hypogaea L.) embryo axes and the development of transgenic plants, Plant Cell Rep. 14 (1995) 699-703.

[16] V.K. Rohini, K.S. Rao, Transformation of peanut (Arachis hypogaea L.): a non-tissue culture based approach for generating transgenic plants, Plant Sci. 150 (2000) 41-49.

[17] D.V.R. Reddy, R. Rajeshwari, N. Iizuka, D.E. Lesemann, B.L. Nolt, T. Goto, The occurrence of Indian peanut clump, a soil-borne virus disease of peanut (Arachis hypogaea) in India, Ann. Appl. Biol. 102 (1983) 305-310.

[18] P. Delfosse, A.S. Reddy, P. Devi, A.K. Murthy, S.V. Wesley, R.A. Naidu, D.V.R. Reddy, A disease of wheat caused by Indian peanut clump virus (IPCV), Plant Dis. 79 (1995) 1074.

[19] D.C. Baulcombe, Mechanisms of pathogen-derived resistance to viruses in transgenic plants, Plant Cell 8 (1996) $1833-1844$

[20] S.V. Wesley, M.A. Mayo, C.A. Jolly, R.A. Naidu, D.V.R. Reddy, M.K. Jana, V.K. Parnaik, The coat protein of Indian peanut clump virus: relationships with other furoviruses and with barley stripe mosaic virus, Arch. Virol. 134 (1994) 271-278.

[21] C. Bragard, G.H. Duncan, S.V. Wesley, R.A. Naidu, M.A. Mayo, Virus-like particles assemble in plants and bacteria expressing the coat protein gene of Indian peanut clump virus, J. Gen. Virol. 81 (2000) 267-272.

[22] T. Murashige, F. Skoog, A revised medium for rapid growth and bioassays with tobacco tissue cultures, Physiol. Plant 15 (1962) 473-497.

[23] O.L. Gamborg, R.A. Miller, K. Ojima, Nutrient requirements for suspension cultures of soybean root cells, Exp. Cell Res. 50 (1968) 151-158.

[24] R.A. Jefferson, Assaying chimeric genes in plants: the GUS gene fusion system, Plant Mol. Biol. Rep. 5 (1987) $387-405$.
[25] R. Topfer, J. Schell, H.H. Steinbiss, Versatile cloning vectors for transient gene expression and direct gene transfer in plant cells, Nucleic Acids Res. 16 (1988) 8725.

[26] J. Sambrook, E.F. Fritsch, T. Maniatis, Molecular Cloning, A Laboratory Manual, second ed., Cold Spring Harbour Laboratory Press, New York, 1989.

[27] S.L. Dellaporta, J. Wood, J.B. Hicks, A plant DNA minipreparation: version II, Plant Mol. Biol. Rep. 1 (1983) 19-21.

[28] L. Marechal-Drouard, P. Guillemaut, A powerful but simple technique to prepare polysaccharide-free DNA quickly and without phenol extraction, Plant Mol. Biol. Rep. 13 (1995) 26-30.

[29] J.D. Hamill, S. Rounsley, A. Spencer, G. Todd, M.J.C. Rhodes, The use of the polymerase chain reaction in plant transformation studies, Plant Cell Rep. 10 (1991) 221-224.

[30] M. Cheng, R.L. Jarret, Z. Li, J.W. Demski, Expression and inheritance of foreign genes in transgenic peanut plants generated by Agrobacterium-mediated transformation, Plant Cell Rep. 16 (1997) 541-544.

[31] M.M. Moloney, J.M. Walker, K.K. Sharma, High efficiency transformation of Brassica napus using Agrobacterium vectors, Plant Cell Rep. 8 (1989) 238-242.

[32] J. Hachey, K.K. Sharma, M.M. Moloney, Efficient regeneration of Brassica campestris using cotyledon explants cultured in vitro, Plant Cell Rep. 9 (1991) 549-554.

[33] N.S. Nehra, R.N. Chibbar, K.K. Kartha, R.S.S. Datla, W.L. Crosby, C. Stushnoff, Agrobacterium-mediated transformation of strawberry calli and recovery of transgenic plants, Plant Cell Rep. 9 (1990) 10-13.

[34] H. Mathews, W. Wagoner, J. Kellogg, R. Bestwick, Genetic transformation of strawberry: stable integration of a gene to control biosynthesis of ethylene, In Vitro Cell. Dev. Biol. 31P (1995) 36-43. 